\title{
ENFEZAMENTOS EM MILHO: EXPRESSÃO DE SINTOMAS FOLIARES, DETECÇÃO DOS MOLICUTES E INTERAÇÕES COM GENÓTIPOS
}

\author{
ELIZABETH DE OLIVEIRA ${ }^{1}$, CHARLES MARTINS DE OLIVEIRA ${ }^{1}$, ISABEL R. P. DE SOUZA ${ }^{1}$, \\ PAULO CÉSAR MAGALHÃES ${ }^{1}$, IVAN CRUZ ${ }^{1}$
} ${ }^{1}$ Pesquisadores, Embrapa Milho e Sorgo. Caixa Postal 151, CEP.35701-970 Sete Lagoas, MG. E-mail:
beth@cnpms.embrapa.br (autor para correspondencia).

Revista Brasileira de Milho e Sorgo, v.1, n.1, p.53-62, 2002

\begin{abstract}
RESUMO- Com o objetivo de verificar a multiplicação, expressão de sintomas foliares e efeito dos molicutes na produção de diferentes genótipos de milho, fitoplasma e Spiroplasma kunkelii foram inoculados, isolada ou simultaneamente, em cinco cultivares, mantidas em vasos até a produção. Plantas sadias de todas as cultivares foram utilizadas como controle. Em cada vaso, foram cultivadas duas plantas, sendo uma utilizada para a detecção dos molicutes na última folha completamente expandida, aos 30,60 e 100 dias após a inoculação. A outra planta foi utilizada para detecção dos molicutes nas folhas inferiores, medianas e apicais, aos 100 dias após a inoculação. O percentual de redução causado pelos molicutes na altura e na produção de grãos foi determinado nas duas plantas, em relação às plantas sadias. A expressão de sintomas foliares e os resultados positivos obtidos na detecção dos molicutes foram mais evidentes aos 100 dias após a inoculação. O período de enchimento de grãos foi considerado a fase mais adequada para a detecção desses patógenos. Os molicutes foram detectados nas folhas inferiores, medianas e apicais, observando-se maior freqüência nas folhas apicais. Verificou-se predominância de infecção por espiroplasma e maior efeito detrimental desse patógeno no crescimento e produção das plantas em relação ao fitoplasma. Não foi detectado efeito sinergístico significativo dos dois molicutes sobre o crescimento e produção das plantas. Observou-se que o efeito prejudicial desses patógenos sobre o crescimento e produção das cultivares foi determinado pela freqüência de plantas infectadas.
\end{abstract}

Palavras-chave: fitoplasma, espiroplasma, multiplicação.

\section{CORN STUNT DISEASES: LEAVES SYMPTOMS EXPRESSION, MOLLICUTES DETECTION AND INTERACTIONS WITH GENOTYPES}

\begin{abstract}
The objective of this work was to evaluate the multiplication, leaves symptoms expression and the effects of mollicutes in maize. In order to accomplish this goal, phytoplasma and Spiroplasma kunkelli were inoculated isolatedly or simultaneously in five maize cultivars, grown under pot conditions. Healthy plants from all genotypes were used in this experiment as a control. Two plants were grown per pot being one of them used to mollicutes detection, by using the last leaf completely developed at 30,60 and 100 days after inoculation. The other plant was used to mollicute's detection at 100 days after inoculation by using the leaves located at the botton, median and apical parts of the plants. Reduction percentage caused by mollicutes in height and plant grain production was evaluated in both plants in relation to the healthy ones. The expression of leaf symptoms and the positive results obtained by mollicutes detection were more evident 100 days after inoculation. The grain filling stage was considered to be more adequate for these pathogens detection. Among the three-leaf positions the detection was
\end{abstract}


observed more frequently at the apical leaf position. The results showed predominance of spiroplasma infection and greater detrimental effect of this pathogen in the plant growth and production when compared to phytoplasma infection. It was not detected significant synergistic effect of both mollicutes on the plant growth and production. The pathogen effect on growth and cultivar production was determined by the frequency of infected plants.

Key words: phytoplasma, spiroplasma, multiplication.

Surtos de doenças causadas por molicutes podem resultar em perdas expressivas na produção de grãos de milho, no Brasil (Oliveira et al., 1998). Essas doenças, denominadas Enfezamento Pálido (Corn Stunt Spiroplasma) e Enfezamento Vermelho (Maize Bushy Stunt Phytoplasma), estão associadas à infecção dos tecidos do floema das plantas de milho, respectivamente, por espiroplasma (Spiroplasma kunkelii Whitcomb) e por fitoplasma (Davis \& Worley, 1973; Bascopé \& Galindo, 1981). Esses microorganismos são transmitidos de plantas de milho doentes para plantas de milho sadias, através de insetos vetores (Nault, 1980). No Brasil, o milho é seu único hospedeiro e a cigarrinha Dalbulus maidis, a única espécie de inseto vetor conhecida (Oliveira, 1996). A transmissão desses patógenos pela cigarrinha é do tipo persistente propagativa, sendo o período latente entre a aquisição e o início da transmissão de cerca de quatro semanas (Nault, 1980).

Os sintomas do Enfezamento Vermelho são, em geral, caracterizados pelo avermelhamento generalizado, proliferação de espigas, redução em altura da planta e, dependendo da cultivar, perfilhamento nas axilas foliares ou na base da planta. Os sintomas do Enfezamento Pálido caracterizam-se pela presença de faixas cloróticas ou esbranquiçadas, que se estendem da base em direção ao ápice das folhas, acentuada redução na altura das plantas e no tamanho das espigas, embora existam relatos de proliferação de espigas e de algum avermelhamento foliar em plantas com Enfezamento Pálido. Em geral, os sintomas dessas doenças manifestam-se tipicamente na época do enchimento de grãos (Nault,
1980; Massola Jr. 1998). Assim, a diagnose dos enfezamentos causados pelos molicutes e, particularmente, a distinção entre o Enfezamento Pálido e o Enfezamento Vermelho, com base apenas nos sintomas apresentados pelas plantas, pode ser muito difícil, ou mesmo impossível, uma vez que esses sintomas podem ser muito variáveis em função da cultivar, idade em que a planta foi infectada e ambiente (Nault 1980; Toffanelli \& Bedendo, 2001). Freqüentemente, para a realização de um diagnóstico preciso dessas enfermidades, há necessidade de detecção dos molicutes nos tecidos foliares, que pode ser feita por PCR ou por testes sorológicos (Lee et al., 1993; Harrison et al., 1996; Barros et al., 2001; Oliveira et al.,1998). Entretanto, freqüentemente, amostras de folhas de plantas de milho apresentando sintomas de enfezamentos podem apresentar resultado negativo para a presença desses patógenos, quando analisadas em testes sorológicos ou através de PCR, sendo essa limitação atribuída ao seu baixo título e distribuição desuniforme na planta (Oliveira et al., 1998).

O objetivo desse trabalho foi verificar a multiplicação de molicutes em diferentes genótipos de milho, sua relação com a expressão de sintomas foliares e efeito na produção, visando a padronização de amostragem para detecção desses patógenos e diagnose das doenças que causam.

\section{Material e Métodos}

Foi conduzido um experimento em viveiro telado, em esquema fatorial $5 \times 4$, sendo: cinco cultivares de milho (Pop Zélia, BR 3123, BR 201, D 766, 
C 855) e quatro tratamentos de inoculação (plantas sadias, inoculação com fitoplasma, inoculação com espiroplasma, inoculação simultânea com fitoplasma e com espiroplasma). Cada tratamento foi repetido três vezes, em delineamento experimental inteiramente ao acaso, sendo cada parcela experimental constituída por um vaso contendo $20 \mathrm{~kg}$ de substrato e duas plantas.

Utilizou-se como substrato Latossolo Vermelho Escuro, fase cerrado, com os seguintes atributos químicos: $\mathrm{pH}_{\text {água }} 6,6$; Ca e $\mathrm{Mg}$ extraído com $\mathrm{KCl} 1 \mathrm{~N}$, respectivamente, 6,78 e $0,87 \mathrm{cmol} \mathrm{kg}^{-1}$, o K e o P extraído pelo Mehlich 1, respectivamente, 65 e $8 \mathrm{mg} \mathrm{kg}^{-1}$ (Vettori, 1969). No plantio, foram utilizados $98 \mathrm{mg} \mathrm{kg}^{-1}$ de $\mathrm{N} ; 150 \mathrm{mg} \mathrm{kg}^{-1}$ de $\mathrm{P}_{2} \mathrm{O}_{5}$, $197 \mathrm{mg} \mathrm{kg}^{-1}$ de $\mathrm{K}_{2} \mathrm{O}$ e $10 \mathrm{mg} \mathrm{kg}^{-1}$ de $\mathrm{Zn}$. A adubação de cobertura foi efetuada semanalmente, aplicando-se o equivalente a $20 \mathrm{mg} \mathrm{kg}^{-1} \mathrm{de} \mathrm{N}$, através do sulfato de amônio.

Em cada vaso, foram semeadas cinco sementes e, após a emergência, foi feito o desbaste, deixando-se duas plantas. Aos três dias após a emergência, foram feitos os tratamentos de inoculação, utilizando-se espécimens de cigarrinhas Dalbulus maidis, infectivas com molicutes ou sadias, previamente obtidas sob condições controladas.

Para a inoculação do fitoplasma ou do espiroplasma, foram confinadas, em cada planta, duas cigarrinhas infectivas, com apenas um desses patógenos, sob gaiolas de plástico transparente e com aberturas cobertas com tecido "voil", para ventilação. Para a inoculação simultânea dos dois patógenos, foram confinadas em cada planta quatro cigarrinhas, sendo duas infectivas com fitoplasma e duas infectivas com espiroplasma.

O período de acesso à inoculação (PAI) foi de quatro dias, correspondente ao tempo em que as cigarrinhas permaneceram confinadas nas plantas. No tratamento "plantas sadias", em cada planta foram confinadas duas cigarrinhas sadias.
Para a obtenção das cigarrinhas sadias, espécimes adultos foram confinados por três dias, em plântulas de milho mantidas em gaiolas de tecido "voil", para a realização de postura, sendo os ovos posteriormente removidos para placas de Petri contendo papel de filtro úmido e incubados à temperatura ambiente, até a eclosão de ninfas. Essas ninfas foram utilizadas para o estabelecimento da população sadia, em gaiolas de tecido "voil", sempre alimentadas com plântulas de milho sadias.

As populações de cigarrinhas infectivas com fitoplasma ou com espiroplasma foram obtidas através do confinamento de ninfas sadias em $2^{\circ}$ ou em $3^{\circ}$ estádio, em plantas de milho infectadas por apenas um desses patógenos, durante quatro dias, para aquisição, aguardando-se posteriormente quatro semanas de período latente, antes de sua utilização para a inoculação, com base em metodologia utilizada por Nault (1980).

As plantas utilizadas como fonte de inóculo foram obtidas através do isolamento de fitoplasma e de espiroplasma, a partir de plantas infectadas em campo, após prévia confirmação de infecção por apenas um desses patógenos, utilizando-se cigarrinhas sadias, e mantidas em casa-de-vegetação através de transmissões contínuas para novas plântulas sadias. Após as inoculações, o experimento foi semanalmente pulverizado com inseticida imidacloprid, para a eliminação de possíveis ninfas provenientes da postura das cigarrinhas utilizadas para a inoculação.

Todas as plantas foram avaliadas aos 30 , 60 e 100 dias, com relação à expressão de sintomas foliares de infecção por molicutes. Foram considerados sintomas de infecção por molicutes a presença de avermelhamento ou amarelecimento nas margens e/ou no ápice das folhas e a presença de estrias esbranquiçadas, iniciando-se na base das folhas, típicas da infecção por espiroplasma (Nault, 1980). 
Em uma das plantas de cada vaso, a última folha completamente expandida foi coletada aos 30 , 60 e 100 dias após a realização das inoculações, e submetidas ao teste PCR, para a detecção de fitoplasma e de espiroplasma, sendo essas idades correspondentes, respectivamente, a plantas jovens, plantas em florescimento, plantas em enchimento de grãos. Na outra planta, coletou-se, aos 100 dias após inoculação, a folha apical, uma folha ao meio e outra no terço inferior da planta, para a detecção desses patógenos por PCR.

A detecção dos patógenos foi feita através de PCR multiplex, utilizando-se, para a detecção de espiroplasma, os oligonucleotídeos: CSSF2: 5'GGC AAA AGA TGT AAC AAA AGT-3' e CSSR6: 5'-GTT TAC TTC AAC AGT AGT TGC G-3' (Barros et al. 2001); para a detecção de fitoplasma, os oligonucleotídeos: R16F2: 5'-ACG ACT GCT GCT AAG ACT GG-3' e R16R2: 5'TGA CGG GCG GTG GTA CAA ACC CCG-3' e condições de reação descritas por Lee et al. (1993).

O crescimento e a produção das plantas foram avaliados através da determinação da altura das plantas e do peso seco de grãos, nas duas plantas de cada vaso. A altura de cada planta foi medida do nível do solo até a folha-bandeira. A colheita foi feita ao final do ciclo e os grãos foram secos em estufa a $70^{\circ} \mathrm{C}$, com ventilação, até peso constante.

$\mathrm{O}$ experimento foi conduzido em viveiro telado e com cobertura plástica, na Embrapa Milho e Sorgo, em Sete Lagoas, MG, durante o período de maio a setembro de 2001. As médias de temperatura máxima, de temperatura mínima e de umidade relativa do ar, registradas mensalmente no local, durante esse período, encontram-se na Tabela 1.

Utilizando-se os dados obtidos para altura de plantas e para peso seco de grãos, foi calculado, para cada planta submetida à inoculação com molicutes, o percentual de redução causado pela inoculação em relação às plantas sadias. Para a realização desses cálculos de redução, tomou-se por base, para cada cultivar, a média de produção das plantas sadias. Os resultados obtidos para esses percentuais de redução foram submetidos à análise estatística de variância, após transformação dos dados por arc sen raiz de $\mathrm{x}$, através do programa estatístico MSTATC.

TABELA 1. Médias mensais de temperatura máxima (Tmax), temperatura mínima (Tmin) e umidade relativa do ar (UR) na Embrapa Milho e Sorgo, em Sete Lagoas, MG, no período de maio a setembro de 2001.

\begin{tabular}{lccc}
\hline & Tmax $\left({ }^{\circ} \mathrm{C}\right)$ & $\mathrm{Tmin}\left({ }^{\circ} \mathrm{C}\right)$ & UR $(\%)$ \\
\hline Maio & 27,92 & 14,5 & 61,29 \\
Junho & 27,09 & 13,43 & 59,92 \\
Julho & 27,49 & 12,64 & 56,42 \\
Agosto & 26,73 & 13,18 & 52,98 \\
Setembro & 29,90 & 16,68 & 59,24 \\
\hline
\end{tabular}

\section{Resultados e Discussão}

Aos 100 dias após a inoculação, a maioria das plantas dos tratamentos de inoculação com espiroplasma ou simultaneamente, com espiroplasma e fitoplasma, manifestaram sintomas foliares de avermelhamento e/ou amarelecimento nas margens e ápice das folhas e, algumas cultivares, presença de estrias esbranquiçadas, características da infecção por espiroplasma (Tabela 2). A predominância desses três sintomas foi variável para as diferentes cultivares, observando-se maior tendência de avermelhamento para as cultivares C 855 e BR 3123, seguidas pela cultivar D 766. No tratamento de inoculação com fitoplasma, foi relativamente menor a freqüência de plantas apresentando sintomas foliares, para todas as cultivares.

Independentemente das cultivares, da inoculação com fitoplasma ou com espiroplasma, ou com ambos, e do tipo de sintoma foliar, aos 30, 60 e 100 dias após a inoculação, respectivamente cerca de 11, 42 e 70\% das plantas apresentaram algum sintoma foliar indicativo de infecção por molicutes. 
TABELA 2. Expressão de sintomas foliares em plantas de milho de diferentes cultivares infectadas por molicutes, aos 100 dias após a inoculação. ${ }^{(*)}$

\begin{tabular}{|c|c|c|c|c|c|c|c|c|c|c|c|c|}
\hline & \multicolumn{3}{|c|}{ Fitoplasma } & \multicolumn{3}{|c|}{ Espiroplasma } & \multicolumn{3}{|c|}{$\begin{array}{l}\text { Fitoplasma e } \\
\text { Espiroplasma }\end{array}$} & \multicolumn{3}{|c|}{ Sadia } \\
\hline & V & $\mathrm{B}$ & A & V & B & A & V & B & A & V & B & A \\
\hline & & $\%$ & & & $\%$ & & & $\%$ & & & $\%$ & \\
\hline D 766 & 16,7 & 0,0 & 16,7 & 50,0 & 50,0 & 50,0 & 16,7 & 16,7 & 66,7 & 0,0 & 0,0 & 0,0 \\
\hline C 855 & 33,3 & 0,0 & 16,7 & 83,3 & 0,0 & 50,0 & 83,3 & 16,7 & 50,0 & 0,0 & 0,0 & 0,0 \\
\hline Pop Zélia & 16,7 & 0,0 & 0,0 & 33,3 & 33,3 & 33,3 & 33,3 & 50,0 & 33,3 & 0,0 & 0,0 & 0,0 \\
\hline BR 3123 & 16,7 & 0,0 & 16,7 & 66,7 & 33,3 & 33,3 & 83,3 & 0,0 & 83,3 & 0,0 & 0,0 & 0,0 \\
\hline BR 201 & 0,0 & 0,0 & 0,0 & 16,7 & 0,0 & 16,7 & 50,0 & 33,3 & 50,0 & 0,0 & 0,0 & 0,0 \\
\hline
\end{tabular}

$\mathrm{V}=$ avermelhamento; $\mathrm{B}=$ presença de estrias esbranquiçadas; $\mathrm{A}=$ amarelecimento.

(*) Dados referentes a seis plantas por tratamento de inoculação.

A Figura 1 mostra os resultados das análises PCR para detecção de fitoplasma e de espiroplasma nas plantas inoculadas com esses molicutes isolada ou simultaneamente. Verifica-se que, aos 30 dias após a inoculação, apenas a presença de fitoplasma foi detectada, e em apenas três plantas, dentre 15 analisadas. Aos 60 e 100 dias após a inoculação, o número de plantas em que a presença desses patógenos foi detectada aumentou, verificando-se predominância de espiroplasma em relação ao fitoplasma. Esse resultado sugere maior agressividade e capacidade multiplicativa do espiroplasma em relação ao fitoplasma ou, por outro lado, maior resistência das cultivares ao fitoplasma que ao espiroplasma, portanto, com provável diferença nos mecanismos de resistência aos dois patógenos.
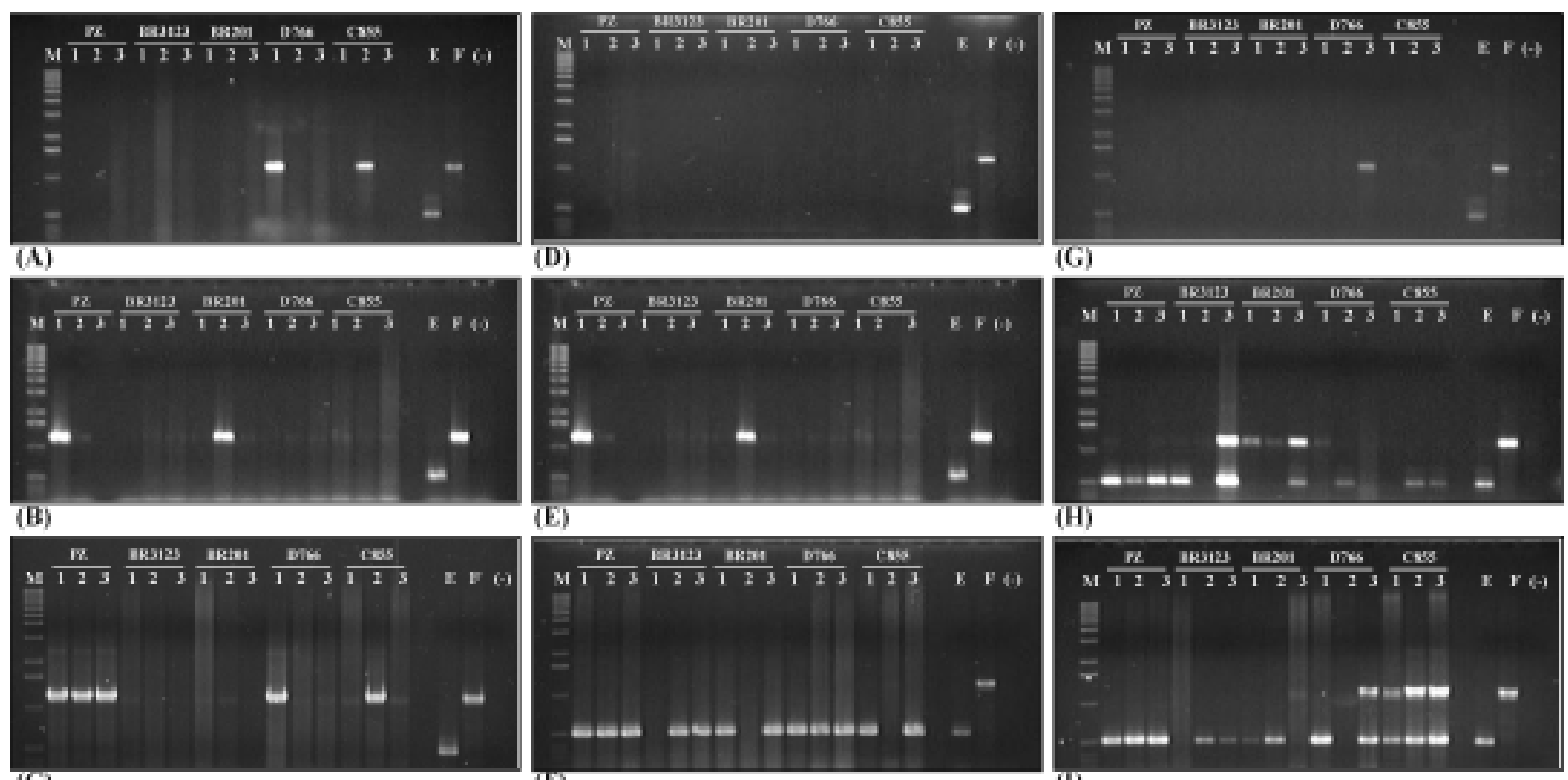

(E)

(H)
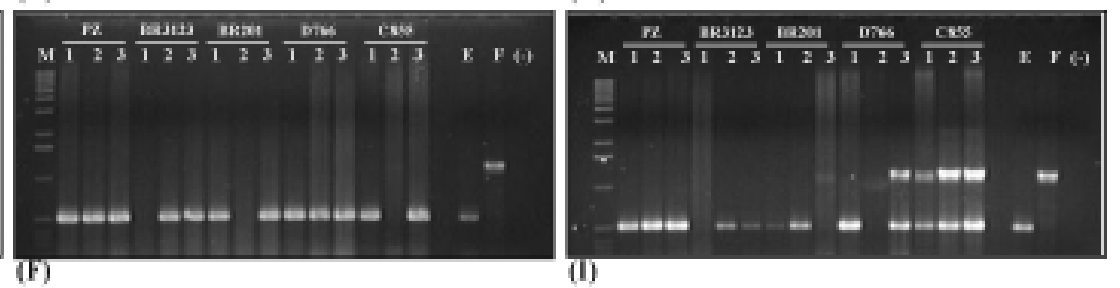

FIGURA 1. Resultados de PCR para a detecção dos molicutes aos 30, 60 e 100 dias após inoculação: fitoplasma (A-30 dias; B-60 dias e C-100 dias); espiroplasma (D-30 dias; E- 60 dias e F-100 dias); fitoplasma + espiroplasma (G-30 dias; $\mathrm{H}-60$ dias e I-100 dias). 
A ausência dos molicutes na última folha completamente desenvolvida, aos 30 dias após a inoculação, evidencia um longo período latente desses patógenos na planta, que, se associado ao período latente no vetor antes do início de sua transmissão, que é cerca de quatro semanas, poderia atrasar muito a disseminação de inóculo secundário no campo e, conseqüentemente, o progresso da doença. Nesse caso, a disseminação dos molicutes nas lavouras de milho seria totalmente dependente do inóculo inicial proporcionado pela migração de cigarrinhas infectivas de lavouras em fase de produção para lavouras jovens.

Contudo, Gussie et al. (1995) detectaram, através de teste ELISA, a presença de espiroplasma em folhas de plântulas de milho, 14 dias após a inoculação. Neste estudo, as probabilidades de detecção de espiroplasma em diferentes orgãos da planta, determinada por regressão logística, aumentou com o tempo, sendo maior nas raízes que nas folhas, na maioria das idades testadas. A diferença entre os dois trabalhos, com relação ao tempo de incubação necessário para detecção dos molicutes nas folhas, pode ser provavelmente atribuída às diferenças das condições de temperatura em que foram conduzidos os dois experimentos.

No trabalho de Gussie et al. (1955), as plântulas de milho inoculadas com espiroplasma foram cultivadas em câmara de crescimento com $12 \mathrm{~h}$ de luz a $27^{\circ} \mathrm{C}$ e $12 \mathrm{~h}$ de escuro a $22^{\circ} \mathrm{C}$ e, no presente trabalho, as plântulas de milho inoculadas foram cultivadas em viveiro, sob condições de temperaturas médias máximas de $27,9^{\circ} \mathrm{C}$ e temperaturas médias mínimas de $14,5^{\circ} \mathrm{C}$, durante os 30 dias iniciais de desenvolvimento, e sob temperaturas inferiores nos meses seguintes, exceto ao final do ciclo das plantas (Tabela 1).

Nault (1980) verificou que o período de incubação dos molicutes em milho foi menor quando as plantas infectadas foram cultivadas sob temperatura de $31^{\circ} \mathrm{C}$ durante o dia e $25^{\circ} \mathrm{C}$ durante a noite, em relação a plantas infectadas cultivadas sob temperatura de $27^{\circ} \mathrm{C}$ durante o dia e $18^{\circ} \mathrm{C}$ durante a noite, sendo esse efeito mais acentuado para espiroplasma que para fitoplasma. Assim, esses resultados evidenciam que, particularmente, a multiplicação do espiroplasma nas plantas de milho pode ser beneficiada pelo aumento da temperatura ambiente. Isso significa que o progresso da doença causada por esse molicute pode ser muito acelerado em áreas em que predominam temperaturas elevadas.

Verifica-se também, na Figura 1, que a freqüência de detecção dos molicutes aumentou em função da idade da planta, à semelhança dos resultados obtidos por Gussie et al. (1955). Esse fato permite inferir que as cigarrrinhas migrantes de lavouras de milho com alta incidência de enfezamentos têm alta probabilidade de serem portadoras desses patógenos, promovendo sua disseminação para novas lavouras.

Na Tabela 3, verifica-se, aos 30 e 60 dias após a inoculação, maior freqüência de plantas apresentando apenas sintomas foliares de infecção por molicutes e ausência desses patógenos nos testes de detecção, e também maior freqüência de plantas assintomáticas, em que a presença desses patógenos foi detectada, em relação ao que ocorreu aos 100 dias após a inoculação. Certamente a ocorrência de sintomas não coincidindo com a detecção desses patógenos nas folhas pode ser atribuída à sua distribuição desuniforme na planta. Por outro lado, a ocorrência de plantas infectadas não apresentando sintomas foliares pode ser possivelmente explicada em função da atuação desses patógenos na fisiologia da planta.

Aos 100 dias após a inoculação, a presença dos molicutes foi detectada nas folhas apicais, medianas e inferiores das plantas, verificando-se maior freqüência de detecção, ao menos para espiroplasma, nas folhas apicais (Figura 2). É importante observar que, nesse caso, as variações observadas 
na freqüência de detecção dos molicutes, em função do posicionamento das folhas nas plantas, pode estar mais relacionada à idade dos tecidos, e conseqüente qualidade do DNA extraído para realização dos $\mathrm{PCR}$, que à distribuição desses patógenos na planta. Nesse caso, pode-se considerar mais adequada a amostragem das folhas apicais para detecção desses patógenos, considerando-se que, por serem as últimas formadas na planta, possuem tecidos mais jovens, podendo proporcionar melhor qualidade de DNA para a realização de PCR.

TABELA 3. Plantas de milho de diferentes cultivares submetidas a cigarrinhas portadoras de fitoplasma, espiroplasma, fitoplasma+espiroplasma ou sadias, que apresentaram ou não sintomas foliares e foram positivas ou não pelo teste de PCR, para a presença de fitoplasma ou espiroplasma, aos 30,60 e 100 dias após o período de acesso à inoculação (PAI).

\begin{tabular}{|c|c|c|c|c|c|c|c|c|c|c|c|c|c|}
\hline \multirow{7}{*}{ 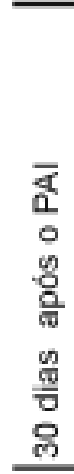 } & & \multicolumn{3}{|c|}{ Fitoplasma } & \multicolumn{3}{|c|}{ Espiroplasma } & \multicolumn{3}{|c|}{$\begin{array}{l}\text { Fitoplasma + } \\
\text { Espiroplasma }\end{array}$} & \multicolumn{3}{|c|}{ Sadia } \\
\hline & & R1 & R2 & R3 & R1 & R2 & R3 & R1 & R2 & R3 & R1 & $\mathrm{R} 2$ & R3 \\
\hline & D 766 (B) & $\mathrm{P}$ & - & - & - & - & - & - & - & ++ & - & -- & - \\
\hline & C $855(\mathrm{~B})$ & -- & $\mathrm{P}$ & - & -- & - & - & - & s & -- & - & -- & -- \\
\hline & Pop Zélia (B) & - & - & - & - & - & - & - & - & - & - & - & - \\
\hline & BR 3123 (B) & -- & -- & s & $\mathrm{s}$ & - & $\mathrm{s}$ & - & - & -. & - & -. & -. \\
\hline & BR 201 (B) & -- & -. & - & - & - & - & - & - & -- & - & - & -- \\
\hline \multirow{5}{*}{ 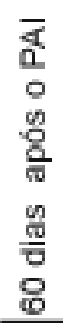 } & D 766 (B) & - & - & - & - & - & ++ & ++ & $P$ & s & - & -- & -- \\
\hline & C 855 (B) & - & s & - & - & - & - & $\mathrm{s}$ & ++ & ++ & - & - & - \\
\hline & Pop Zélia (B) & $\mathrm{P}$ & $\mathrm{P}$ & $\mathrm{s}$ & ++ & ++ & $\mathrm{s}$ & ++ & ++ & ++ & - & -. & -. \\
\hline & BR 3123 (B) & - & -. & - & ++ & ++ & ++ & ++ & S & ++ & - & -. & -. \\
\hline & BR 201 (B) & - & $\mathrm{P}$ & - & $\mathrm{P}$ & - & - & $\mathrm{P}$ & $\mathrm{P}$ & $P$ & - & - & - \\
\hline \multirow{5}{*}{ 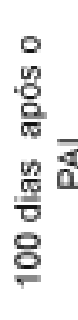 } & D 766 (B) & ++ & -- & $P$ & ++ & ++ & ++ & ++ & - & ++ & - & - & -- \\
\hline & C 855 (B) & $\mathrm{P}$ & ++ & $P$ & ++ & s & ++ & ++ & ++ & ++ & - & -- & -- \\
\hline & ZPop Zélia (B) & ++ & ++ & ++ & ++ & ++ & ++ & ++ & ++ & ++ & - & - & - \\
\hline & BR 3123 (B) & -- & - & - & -- & ++ & ++ & - & ++ & ++ & - & -. & -. \\
\hline & BR 201 (B) & S & - & - & ++ & - & ++ & ++ & ++ & -- & - & -- & -- \\
\hline
\end{tabular}

++ Plantas que apresentaram sintomas foliares de enfezamento e foram positivas para a presença de fitoplasma ou espiroplasma pelo teste de PCR;

- Plantas que não apresentaram sintomas foliares de enfezamento e foram negativas para a presença de fitoplasma ou espiroplasma pelo teste de PCR;

S. Plantas que apresentaram sintomas foliares de enfezamento e foram negativas para a presença de fitoplasma ou espiroplasma pelo teste de PCR;

P. Plantas que não apresentaram sintomas foliares de enfezamento e foram positivas para a presença de fitoplasma ou espiroplasma pelo teste de PCR; 
Verifica-se ainda, nas Figuras 1 e 2, que, aos 100 dias após a inoculação, os molicutes atingiram todas as folhas das plantas de milho, sendo, portanto, essa a melhor idade para a realização de amostragens para sua detecção, ou seja, durante o enchimento de grãos.

A redução em produção das plantas de milho foi significativamente diferente $(\mathrm{P}<0,01)$ para fitoplasma e espiroplasma, sendo maior quando as plantas foram infectadas por espiroplasma (Figura 3). Entretanto, a inoculação simultânea desses dois patógenos não resultou em efeito sinergístico aumentando essa redução. Observa-se também, na Figura 3, que a redução em altura não foi significativamente diferente para plantas inoculadas com fitoplasma, com espiroplasma ou com ambos.

Apesar da variação observada com relação ao efeito dos molicutes na redução em crescimento e produção, em função das cultivares avaliadas (Figura 4), a análise estatística de variância não mostrou diferença significativa. Esse resultado pode ser atribuído à grande variação nos dados obtidos $(\mathrm{CV}=66,7 \%)$, devido ao fato de várias plantas submetidas aos tratamentos de inoculação não se tornarem infectadas. Observa-se, por exemplo, na Figura 3 que, a cultivar BR 201 apresentou o menor percentual de redução em crescimento e produção, em relação às outras cultivares, causada tanto por fitoplasma quanto por espiroplasma. Porém, observa-se, nas Figuras 1 e 2, que, aos 100 dias após a inoculação, a presença de espiroplasma e de fitoplasma foi detectada em menos de $50 \%$ das plantas do BR 201, submetidas à inoculação. Ressalta-se que a ausência de molicutes nessas plantas não deve ser atribuída ao escape à inoculação, considerando-se que as cigarrinhas infectivas permaneceram confinadas nas plantas durante quatro dias, e que já foi anteriormente demonstrado por Oliveira et al. (2001) não haver diferença entre o confinamento de uma a dez cigarrinhas por planta para a obtenção de infecção por esses patógenos.
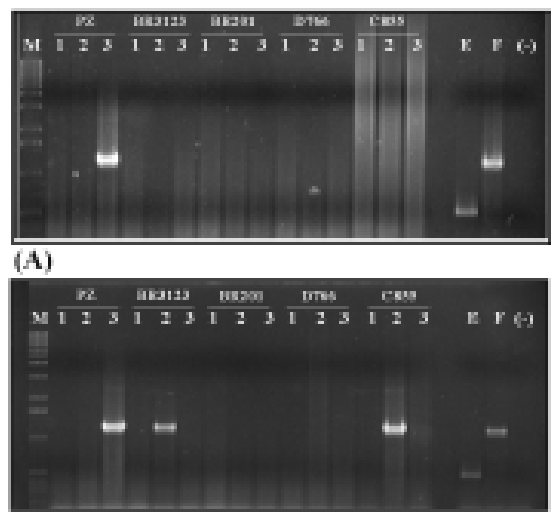

(B)

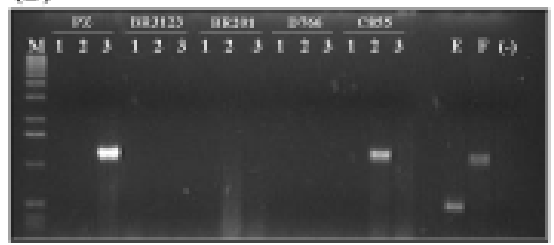

(C)
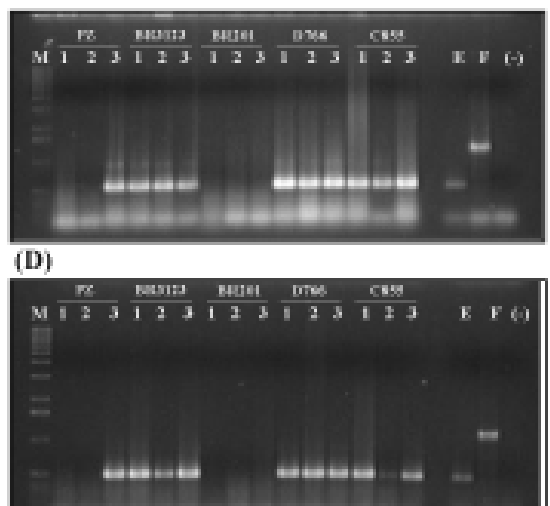

(E)

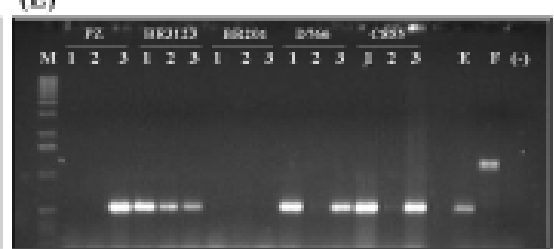

(F)

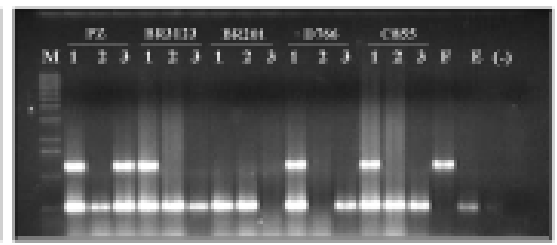

(G)

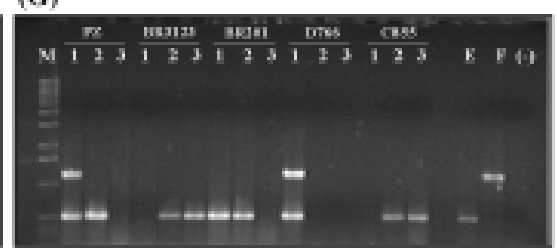

(H)

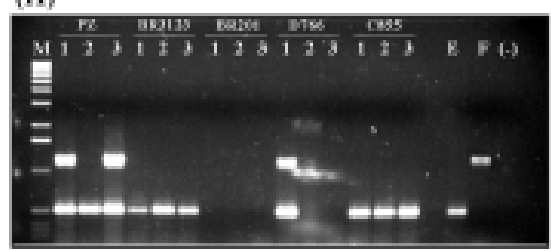

(I)

FIGURA 2. Resultados de PCR para a detecção dos molicutes, aos 100 dias após a inoculação: fitoplasma (A-folha apical; B-folha mediana e C-folha inferior); espiroplasma (D-folha apical; E-folha mediana e F-folha inferior); fitoplasma + espiroplasma (G-folha apical; $\mathrm{H}$-folha mediana e I-folha inferior). 


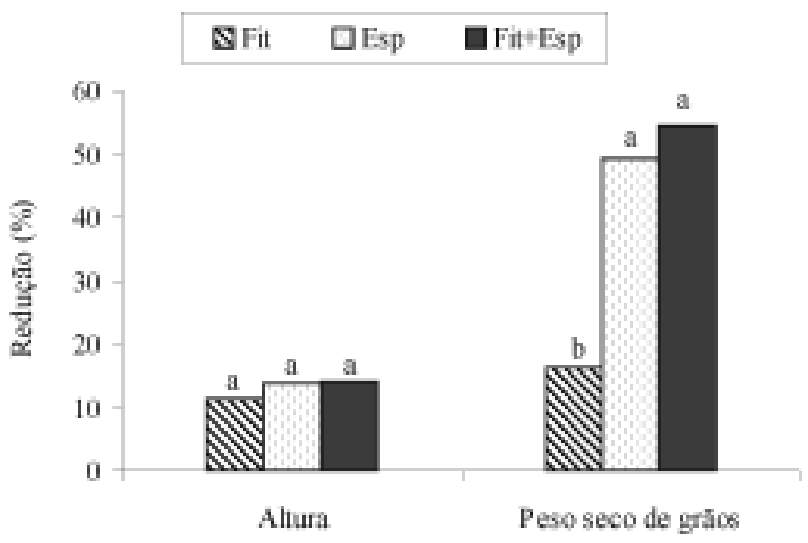

FIGURA 3. Percentual médio de redução em altura de plantas e em peso seco de grãos causada pela inoculação de fitoplasma (Fit), de espiroplasma (Esp) e de fitoplasma + espiroplasma (Fit + Esp) em diferentes cultivares de milho. Barras seguidas de mesma letra não diferem entre si pelo teste de Tukey ao nível de 0,05 de probabilidade.

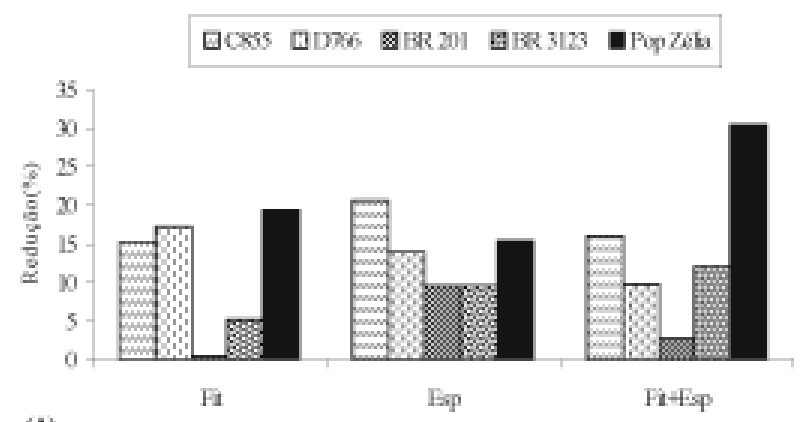

(A)

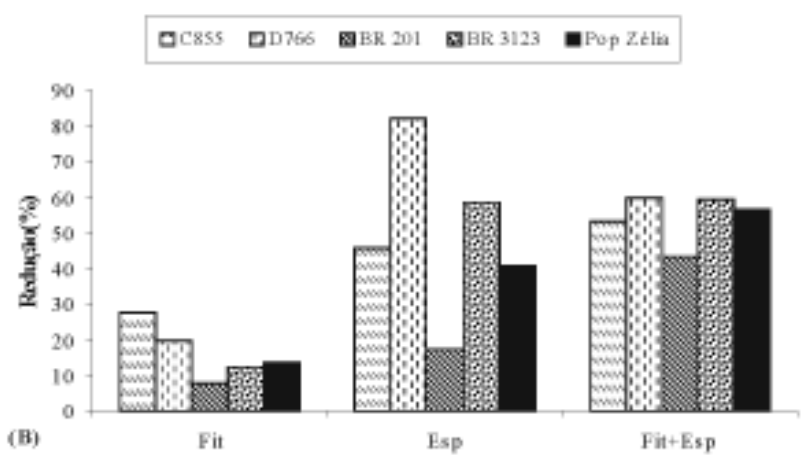

FIGURA 4. Percentual médio de redução em altura (A) e em peso seco de grãos (B) causada pela inoculação de fitoplasma (Fit), espiroplasma (Esp) e fitoplasma + espiroplasma (Fit + Esp) em diferentes cultivares de milho.
Portanto, aparentemente, a magnitude do efeito dos molicutes na redução em produção de cada cultivar de milho é determinada antes pelo número de plantas infectadas e não por um determinado nível de resistência das plantas infectadas que possa minimizar o efeito prejudicial desses patógenos sobre a produção. Assim, pode-se inferir, com base nos resultados apresentados, que os alelos envolvidos na resistência aos molicutes não estão uniformemente distribuídos nas plantas das diferentes cultivares, ou que os alelos que conferem essa resistência apresentam penetrância incompleta.

\section{Conclusões}

1- A expressão de sintomas foliares em diferentes cultivares de milho infectadas por fitoplasma ou por espiroplasma varia entre amarelecimento ou avermelhamento foliar e varia também em intensidade de avermelhamento.

2- Plantas de milho infectadas por molicutes nos estádios iniciais de desenvolvimento apresentam expressão máxima de sintomas na época do enchimento de grãos.

3- Maior efetividade na detecção de molicutes em milho pode ser obtida em amostras de folhas apicais, provenientes de plantas em fase de enchimento de grãos.

4- A magnitude da redução em produção causada por molicutes é variável para diferentes cultivares de milho e depende essencialmente da freqüência de plantas susceptíveis à infecção por esses patógenos.

\section{Literatura Citada}

BARROS, T.S.L.; DAVIS, R.E.; RESENDE, R. O. Design of a polymerase chain reaction for specific detection of corn stunt spiroplasma, Spiroplasma kunkelii. Plant Disease, St. Paul, v.85, p.475-480, 2001. 
BASCOPÉ, Q.B.; GALINDO A. J. Naturaleza micoplásmica de la raza "mesa central" del achaparramiento del maiz. Revista Fitopatologia, México, v.16, n. 1, p.28-33, 1981.

DAVIS, R.E.; WORLEY, J.F. Spiroplasma: motile, helical microorganism associated with corn stunt diseases. Phytopathology, St. Paul, v. 63, p.403408, 1973.

GUSSIE, J. S.; FLETCHER, J.; CLAYPOOL, P.L. Movement and multiplication of Spiroplasma kunkelii in corn. Phytopathology, St. Paul, v.85, n.10, p.1093-1098, 1995.

HARRISON, N. A., RICHARDSON, P. A.; TSAI, J.H. PCR assay for detection of the phytoplasma associated with maize bushy stunt disease. Plant Disease, St. Paul, v.80, n.3, p.263-269, 1996.

LEE, I.M., HAMMONS, R.W., DAVIS, R.E.; GUNDERSEN, D.E. Universal amplification and analysis of pathogen $16 \mathrm{~S} \mathrm{r}$ DNA for classification and indentification of mycoplasmalike organisms. Phytopathology St. Paul, v.83, n.8, p.834-842, 1993.

MASSOLA JUNIOR, N. S. Avaliação de danos causados pelo enfezamento vermelho e enfezamento pálido na cultura do milho. 1998. 75f. Tese (Doutorado) - Universidade de São Paulo, Escola Superior de Agricultura Luis de Queiroz, Piracicaba.

NAULT, L.R. Maize bushy stunt and corn stunt: a comparison of disease symptoms, pathogen host ranges, and vectors. Phytopathology, St. Paul, v.70, n. 7, p. 659-662, 1980.

OLIVEIRA, C.M. Variação morfológica entre populações de Dalbulus maidis (DeLong \& Wolcott, 1923) (Hemiptera: Cicadellidae) de algumas localidades do Brasil. 1996. 69f. Tese (Mestrado) - Universidade de São Paulo, Escola Superior de Agricultura "Luiz de Queiros", Piracicaba.

OLIVEIRA, C. M. ; OLIVEIRA, E.; CRUZ, I. Efeito de diferentes densidades do vetor Dalbulus maidis (Hemiptera: Cicadellidae) na severidade de doenças causadas por fitoplasma e por Spiroplasma kunkelii em milho. Fitopatologia Brasileira, Brasília, v. 26, p.509, 2001. Suplemento.

OLIVEIRA, E; WAQUIL, J. M.; FERNANDES, F. T.; PAIVA, E. RESENDE, R. O. \& KITAJIMA, W. E. Enfezamento pálido e enfezamento vermelho na cultura do milho no Brasil Central. Fitopatologia Brasileira, Brasília, v.23, n.1, p.45-47, 1998.

TOFFANELLI, C.M.; BEDENDO, I.P. Alterações quantitativa e qualitativa dos componentes de produção de híbridos de milho inoculados com o fitoplasma do Enfezamento Vermelho. Fitopatologia Brasileira, Brasília v.26, p.508, 2001. Suplemento.

VETTORI, L. Métodos da análise do solo. Rio de Janeiro: EPE, 1969. 24p (Boletim Técnico, 7). 